\title{
THE ENERGY SECTOR IN THE PROCESS OF ACHIEVING SUPERPETROSTATE STATUS IN THE LIGHT OF STRATEGIC DOCUMENTS OF THE RUSSIAN FEDERATION
}

\begin{abstract}
This study presents an analysis of program assumptions regarding the energy policy of the Russian Federation. The research methodology involves an analysis of normative acts, current data, and a review of the academic literature. I conclude that the Russian Federation uses the hydrocarbon transmission system to achieve the status of an energy superpower and is able to use its resources and infrastructure to act as an important player in the international arena. The transformation of the energy sector is not only limited to measures aimed at increasing efficiency, but it also plays a decisive role in building the state's potential and co-creating the essential instruments of international influence. Through building the net of pipelines, the Kremlin is consistently able to attain its geopolitical aims. Inefficient attempts to break out of Russian domination of energy has allowed Russia to maintain its infrastructure monopoly and dominate the gas markets of Central and Eastern Europe.
\end{abstract}

Keywords: Russian Federation, energy policy, transmission system, hydrocarbons.

\section{INTRODUCTION}

The purpose of this study is to present an analysis of program assumptions regarding the energy policy of the Russian Federation, with particular emphasis on the use of the energy raw materials transmission system to achieve the status of an energy superpower, and also an important player on the international arena. To organize research activities, the following thesis was adopted: The Russian Federation has intensified its state activity in the field of energy policy in the last decade, which is to serve the impact on the one hand of the state budget, and on the other to build a strong position in the international arena, and the centrally controlled economy enables the Russian Federation to develop pipeline network on an unprecedented scale.

\section{RUSSIAN ENERGY SECTOR AT THE TURN OF THE 20TH AND 21ST CENTURY}

The power of the USSR was largely based on the extraction and exploitation of natural resources, including primarily oil and natural gas. Natural resources were also an important policy instrument. After the collapse of the Soviet Union, the energy sector struggled with

\footnotetext{
${ }^{1}$ Alicja Żukowska, PhD, The Faculty of Command and Naval Operations, Polish Naval Academy, ul. inż. J. Śmidowicza 69, 80-127 Gdynia; e-mail:a.zukowska@amw.gdynia.pl. ORCID:0000$-0002-1315-8312$.
} 
problems resulting from the fact that oil and gas prices stabilized at a relatively low level of USD 20-30 / barrel. At the same time, Russia's export capacity for these raw materials decreased due to outdated infrastructure and the need to meet the commitments of the former Soviet Union. The post-Soviet system of administering Russian natural resources after the collapse of the USSR was based on the principles established in 1992 as part of the "Strategy for the Energy Development of the Russian Federation". In December 1994, the "Energy Development Strategy of the Russian Federation (main assumptions)" was approved by the government. Afterwards, in May 1995, the President of the Russian Federation issued a decree entitled "Main guidelines for energy policy and restructuring of the fuel and energy industry of the Russian Federation for the years up to 2010", in October "The main guidelines for the energy strategy of the Russian Federation" were approved (Gryz, 2019).

The development of the energy sector in the years 2000-2003 was stimulated by the relative autonomy and investment freedom of large oil companies in the country and the growing demand for oil and gas as well as rising prices of these raw materials on foreign markets. The situation was opposed by the depletion of deposits in Western Siberia and the associated decline in production growth, a new division of ownership in the sector, poor condition of the pipeline network and insufficient capacity of export pipelines, insufficient investments of oil companies in resource recovery, deterioration of the resource base, state monopoly in the field of crude oil transport, excessive fiscalism, inconsistent regulatory system, no guarantee of investment security, high level of corruption (Paszyc, Wiśniewska, 2005).

\section{EVOLUTION OF STRATEGIC DOCUMENTS IN THE FIELD OF RUSSIAN ENERGY SECTOR AND THEIR PRACTICAL IMPLEMENTATION}

Russia has replaced territorial expansion with energy expansion since the takeover of power by W. Putin. President Putin, driven by the need to strengthen the presidential office's position towards other major institutions and political actors in Russia, presented a comprehensive program of the socio-economic development of Russia until 2010. It assumed the implementation of measures to increase the authority of central government, counteracting the widening of the gap between Russia and developed countries and restoring and strengthening Russia's position as one of the world leaders (Potulski, 2011). The vision of conducted policy assumed that the basic Russian national interest was to have the status of a global power capable of creating international order in a supra-regional dimension (Mickiewicz, 2018). In 2003, Russia's Energy Strategy until 2020 was adopted, which assumed that the energy factor will be a fundamental element of national security, and is conditioned by the functioning of the national energy sector (Fredholm, 2005). The implementation of this strategy coincided with an increase in world oil prices, on the basis of which gas prices are indexed. This was undoubtedly one of the most favorable factors that allowed the transformation of Russia, "from a non-functional military power into a new energy power" (Hill, 2004). Based on the provisions of the Russian Federation's Energy Strategy until 2020 Western Europe remains the main direction of oil and gas exports from Russia, hence the importance of transit countries and the clear desire of the Russian Federation to become independent from them by building offshore pipelines. It also provides for significant Asian development. In December 2005, President Putin at a meeting of the Security Council of the Russian Federation outlined the concept of Russia as an 
"energy superpower". He said, among others: "Energy is the most important driving force of global economic development. It has always been so and will remain so for a long time" (Madera 2009).

The concept of Russia emerged as an "energy superpower" based on state-controlled energy companies. The core of the energy strategy due to the specificity of gas trade is primarily the state monopolist in all gas market segments in Russia - Gazprom (Musiałek, 2013).

On the basis of the energy strategy of 2003, the primary goal of political influence towards, the so-called close to abroad countries, was to create a situation that forced economic cooperation and abandonment of projects to develop energy transmission systems. Economic, political and then military instruments were used against countries that made unsuccessful attempts to gain real political sovereignty (Georgia and Ukraine) ${ }^{2}$. The second group of countries in the region are potential partners for whom it was necessary to pursue a two-track policy. These are Kazakhstan and Tajikistan, which due to their geographical location found themselves not only in the Russian, but also in the Chinese sphere of influence. For this reason, Russian policy towards these countries depended on

2 The recognition of the EU area as the primary direction of exports of energy raw materials has determined the position of the transit countries. Russia has taken action to dominate these countries, which was particularly evident in relation to Belarus and Ukraine. The first major gas crisis between Belarus and Russia took place in February 2004. Gazprom, which, due to Minsk's halt to the process of creating a joint venture based on Beltransgas, announced a significant increase in the gas price, for which Minsk did not agree. On February 18, 2004, Russian Gazprom suspended the transfer of raw material to Belarus via the Beltransgas network for 18 hours. This struck not only Belarusian, but also Lithuanian and Polish audiences. Beltransgaz began to retrieve the missing raw material from the Jamal gas pipeline. The crisis ended with Gazprom's actual capitulation forced to unscrew the faucet. The crises in relations on the RF-Belarus line, causing interruptions in the supply of raw material, ended in January 2007. A similar course was attempted to subordinate Ukraine to the strategic interests of RF. In March 2005, Gazprom informed Ukraine that the price of gas would be raised to European market rates. The Ukrainian government has entered into negotiations, the fiasco of which was created by the so-called " Ukrainian gas crisis of 2006". Both sides were unable to reach an agreement on 1 January 2006. Russia has accused Ukraine of stealing \$25 million worth of gas. On January 24, 2006, Naftohaz pleaded guilty to the charges, explaining that the gas was used for heating purposes in Ukraine in January 2006. Finally, under pressure from the European Union, a compromise was reached. The exclusive gas supplier for Ukraine became RosUkrEnergo, in which half of the shares were acquisited by Gazprom (Raś, 2015).

In relation to the Central Asia and Caucasian area, it was to block the possibility of transmission of energy raw materials from the region and the failure of other (non-Russian) international players to take control of deposits. To this end, an unstable ethnic situation was used, but also the ambiguities associated with the legal status of the Caspian Sea. Russia's conflict with Georgia over areas of Abkhazia and South Ossetia has made the Caspian region unstable in the eyes of the whole world and thus reduced its attractiveness in the rivalry of energy power powers (Gołaś, 2011).

Crimea is, from Russia's point of view, a strategic area for many reasons. This is the place from which the Black Sea Fleet can sail to the Mediterranean Sea. There is also a deep-sea port, which can be very helpful with the huge underwater drilling operation in search of hydrocarbons. In addition, Crimea has export terminals in the port of Odessa, military construction shipyards in Mikołajów, refinery, huge chemical plants, silos for grain exports, extensive resources of natural resources. It is estimated that natural gas reserves in the Black and Azov seas, off the coast of Crimea, amount to 2 trillion cubic meters and more than 430 million tonnes of oil (Wyganowski, 2014). 
the nature of Chinese policy. The main goal of Russian policy during this period was to strive for their political and economic domination. The goal was achieved by conducting significant investments and supporting the development of the mining sector and the expansion of the energy storage and transport system.

In connection with the economic crisis of 2008 and the end of five years, there was a need to revise the assumptions of the strategy until now, which resulted in the Energy Strategy of the Russian Federation until 2030, approved in 2009. It developed and concretized the assumptions of the preceding document. It contained provisions about a measurable increase in the extraction and export of energy resources, as well as the necessary and far-reaching modernization of the Russian energy sector. In addition, the authors of the Strategy have prioritized increasing Russia's share in the global energy market, which will undoubtedly serve to strengthen the country's political role in the international arena.

On the basis of the 2009 document, EU Member States continued to be Russia's main outlet for oil and gas, but it should be noted that the share of Asian countries in Russian exports of these raw materials has been systematically growing. The Russian strategy until 2030 forecasted that gas exports in 2030 will be higher by $154-159$ billion $\mathrm{m}^{3}$ compared to 2010. It assumed that in the first period of implementation of the strategy (until 2020), most of the additional raw material will be bought by customers from Europe, and in the second (by 2030) there was to be a reorientation of exports to the Far Eastern market, which would allow the sale of approximately 70-75 billion $\mathrm{m}^{3}$ of gas to customers from China, Korea or Japan. Ultimately, the main recipient of Russian gas would be the PRC. According to the assumptions of the "Energy Strategy until 2030", 22-25\% of exported oil and 19-20\% of exported gas should go to Asia. To this end, measures were taken to enable oil supplies via pipeline to China and the Pacific Coast; gas supplies via pipelines to China and to both Korean countries; development of LNG installations for the needs of the Asian market (Kozłowski, 2017). On May 1, 2014, the heads of Gazprom and the Chinese energy company CNPC signed in Shanghai (in the presence of the presidents of Russia and China) a contract negotiated for many years to supply Russian gas to China. The thirty-year agreement provides for the export of 38 billion $\mathrm{m}^{3}$ of gas annually from Russian East Siberian deposits (Chayanda and Kovykta) via the Siberia Force pipeline (Siberia Force 1), which was commissioned in December 2019. In addition, Russia declared its will to implement the so-called Altai project (according to Gazprom's new nomenclature - Strength of Siberia 2) and the so-called Western route (gas supplies from Western Siberia to northwestern China). The third project announced involves deliveries to China via the Sakhalin-Khabarovsk-Vladivostok gas pipeline. A memorandum between the Russian concern Gazprom and the Chinese company CNPC was concluded in 2015.

In the years 2001-2014 over 20,000 km of gas pipelines were built in Russia, which significantly contributed to the increase in the level of gasification. On the other hand, however, the existing internal transmission infrastructure is significantly depleted. For many years, Gazprom has invested mainly in the construction of new export buses at the expense of renovating the national infrastructure (Kardaś, 2017). In the light of the 2020 energy strategy, Russia is to become the main supplier of energy resources in ensuring international energy security. For this purpose, Russia has undertaken a skillful geopolitical pipeline strategy, involving the construction of transmission routes favorable to the Kremlin and blocking projects competitive or violate Russia's monopolistic position (Ruszel, 2011). 
Russia's strategic interests have required the creation of an unified energy and energy transport infrastructure in the neighboring regions of Europe and Asia, the development of international energy transport systems, and ensuring non-discriminatory energy transit. In order to implement this assumption, measures were taken to build a transmission infrastructure:

- construction of the oil pipeline connecting Eastern Siberia - the Pacific Ocean;

- construction of the "Sever" and "Yug" pipelines;

- construction of "Severniy Potok" (Nord Stream) and "Yuzhniy Potok" (South Stream) gas pipelines;

- the construction of a transit gas pipeline connecting Europe with the Yamal Peninsula was completed;

- seaport infrastructure and liquid hydrocarbon transport systems (oil, condensate, liquefied natural gas etc.) have been developed.

An important role was played by the Yamal-Europe gas pipeline, the construction of which began in 1994, commissioning took place in 1999, but the maximum level of transmission capacity (33 billion $\mathrm{m}^{3}$ of gas per year) was only achieved in 2006 . From that moment, the gas pipeline is used almost fully.

In 2002, the Blue Stream gas pipeline was commissioned, which Russian gas is exported directly from Russia via the Black Sea to Turkey. The gas pipeline with a total capacity of 16 billion $\mathrm{m}^{3}$ is used at $80-90 \%$. The construction cost of the gas pipeline was 2.4 billion USD. The third main route diversifying supply routes to Europe was the Nord Stream gas pipeline. In September 2005, Gazprom, together with the German companies BASF and E.ON, signed a preliminary agreement on the construction of a gas pipeline from Russia to Germany. The construction of the pipeline began on April 9, 2010 - the first thread was commissioned on November 8, 2011, the second in October 2012.

The assumptions of the Energy Strategy FR 2030 give priority to the Baltic Pipeline System (BTS 2), as well as the Eastern Siberia - Pacific Ocean (ESPO) oil pipeline, taking into account the transmission of crude oil as well as the North Stream (Nord Stream) and South Stream (South Stream) pipelines in terms of natural gas transmission. One of the goals expressed in the 2030 strategy is the construction of infrastructure allowing production and transmission of liquefied gas. Currently, there is only one gas liquefaction plant in Russia, launched in 2009 as part of the Sakhalin2 project. The project's shareholders are Gazprom (50\% plus 1 share), the Dutch-British Royal Dutch Shell (27.5\% minus 1 share), Japanese companies Mitsui and Mitsubishi (respectively $12.5 \%$ and $10 \%$ shares). The Yamal LNG project is in an advanced stage. Its shareholders are: Novatek - the largest gas producer in Russia after Gazprom (50.1\% shares), the French group Total (20\% shares), the Chinese group CNPC (20\% shares) and the Chinese Silk Road Fund (9.9\% shares). Gazprom announced plans to build two gas liquefaction plants: in the Russian Far East as part of the Vladivostok LNG project and in the Baltic Sea as part of the Baltic LNG project (Kardaś, 2017).

Strengthening Russia's position in global energy trade was associated with the need to ensure stable and high revenues from the supply of energy carriers on the European market. Russia, in order to obtain a raw material and logistical advantage on European and Central Asian markets, has diversified its markets for Russian energy resources. As part of the adopted energy strategy, it was undertaken to build new transmission installations bypassing countries that were reluctant to the Russian vision of developing the European 
fuel market. This applies especially to Poland, Ukraine and the Baltic States. North Stream is such a project, which directly connected the Russian supplier with the German recipient via the Baltic Sea, depriving Poland and Belarus of the status of transit countries. This weakened the negotiating position of these countries towards the Russian group Gazprom, which ruthlessly represented the interests of the Russian state. it is illustrated by Russia's constant pushing for further gas pipeline projects (Nord Stream 1, South Stream, Turkish Stream, Nord Stream 2), whose important accompanying goal is to build specific regional "gas axes" (Kardaś, 2017). It is worth remembering that these projects did not always guarantee profitability, more often they are motivated by political reasons. An example of this is the Nord Stream gas pipeline ${ }^{3}$, which has made EU Member States even more dependent on Russian supplies. In addition, it revealed the fragile solidarity of EU countries by establishing bilateral cooperation with individual EU members (Czachor, 2009).

The Kremlin controls the pipeline network that runs through Russian territory from the Caspian region and Central Asian countries, and takes measures that prevent the construction of alternative export routes. Russia, however, makes use of raw materials, using them far more effectively than military potential in the Cold War. The use of weapons must take place on a reciprocal basis. Thus, the influence of the Russian state was expanded by entangling Europe with a gas pipeline network. If gas or oil supplies to European countries are blocked - no instrument is available to stop Russia from doing this. By tying up a significant part of the world by pipelines, Russia has obtained much more effective than military potential (Goldmann, 2008).

The Nabucco project ${ }^{4}$ was supposed to be an attempt to answer the EU's problem of becoming addicted to Russian gas, assuming the diversification of supplies through the possibility of purchasing raw materials from sources other than the Russian Federation, thus strengthening the energy security of the European Union. This project was not implemented, and there were several reasons for this. The first was to indicate the introduction of an energy mix, assuming an increase in the use of renewable sources. Another reason was the economic crisis that blocked the investment. The Nabucco project has revealed with fullness the weaknesses of the EU decision-making process and, above all, Russia's lack of a unified position on the issue of a common energy policy. All this allowed Russia to maintain its infrastructure monopoly and the dominance of Russian gas on the markets of Central and Eastern Europe. In addition, it significantly increased the chances of profitability of Russia's South Stream gas pipeline, a planned gas pipeline that crosses the Black Sea, connecting the coasts of Russia and Bulgaria. Gazprom intends to send the first strand of gas through Serbia to Hungary, Slovenia and Austria (Musiałek, 2013). In December 2014, Russia abandoned the construction of the South Stream, in favor of an alternative in the form of cooperation with Turkey as part of Turkish Stream. The new project will lead to Turkey and further to the Greek border instead of via the Black Sea

\footnotetext{
3 The gas pipeline connects Russia (Vyborg) with Germany (Greifswald) via the Baltic Sea, bypassing Poland and the Baltic Republics. The planned route of the gas pipeline passes through the waters of the economic zone of three countries (Finland, Sweden and Denmark) that have agreed to build this investment.

4 The Nabucco project officially started in 2002 and began with initial talks between concerns from countries where the pipeline was to run - Austrian OMV, Turkish BOTAS, Hungarian MOL, Romanian Transgaz and Bulgarian Bulgargaz. Two years later, these entities established a company called Nabucco Gas Pipeline International GmbH.
} 
to Bulgaria (Włodkowska-Bagan, 2017). On October 10, 2016, during President Putin's visit to Istanbul, an intergovernmental agreement was signed on the construction of the Turkish Stream gas pipeline (ratified by Turkey and Russia in December 2016 and February 2017, respectively). In December 2016 and February 2017, contracts were signed between South Stream Transport B.V. controlled by Gazprom and the Allseas Group AG company for laying two offshore sections of the gas pipeline. The implementation of this investment will bring Moscow above all political benefits, expressed in depriving Ukraine of the status of a transit state, bypassing the Baltic countries in the shipment of raw material to Western Europe, indirectly weakening Minsk's position (Kardaś, 2017).

\section{NEW DIRECTIONS EVOLUTION OF THE EXPANSION}

The Arctic areas are strategic for strengthening the position of the energy power. About 200 gas and oil deposits have been discovered in the Arctic Zone of the Russian Federation. Climate warming, resulting in easier access to deposits, and an increase in raw material prices, intensify the plans for exploiting the resources located there (Sergunin, Konyshev 2018). The Kremlin plans to improve raw material extraction technology and expand land infrastructure, but Russia's weakness is the lack of capital for necessary investments in the Arctic region. Russia still does not have modern technologies that allow drilling in difficult arctic conditions (Zolotova, 2014). Russian oil extracted from the Arctic, called Arctic Oil (ARCO), entered the global market in 2014. It comes from the newly built and so far the only Prirazłomnaja platform in the Pecs Sea (Szoszyn, 2019). Despite this, actions are taken to prove the thesis that the Siberian shelf and the Arctic bottom are one, which would mean that Russia has the right to these areas, extending even beyond the North Pole and covering most of the Lomonosov Ridge (Rzeszutko-Piotrowska, 2014). Russia is striving to secure its interests ${ }^{5}$ as far as possible, strengthening its military presence in this region, re-opening military bases from the USSR era. The ordinances ${ }^{6}$ of June 14, 2019 assume increasing the transshipment capacity of Arctic transport corridor based on the North Sea $\operatorname{Road}^{7}$, i.e. giving the Dikson seaport the status of an international port and increasing its transshipment capacity (construction of the terminal) for crude oil.

\section{CURRENT STRATEGIC DOCUMENTS SETTING THE ENERGY POLICY IN NEW DIRECTIONS OF THE EXPANSION}

In 2015, the energy strategy was amended. Apart from the sanctions imposed on Russia after the annexation of Crimea, the factor enforcing the modifications in the document binding until now was normalized in the so-called III EU Climate Package. The

\footnotetext{
5 On March 28, 2019, Regulation No. 554 of the Government of the Russian Federation was issued, which provides for the extension of the Sabetta sea port area, including construction of a natural gas handling terminal and its condensate, including a station for compressing (liquefying) gas from the Salmanowski Basin located on the Gudan Peninsula.

6 This legislation is the consequence of strategic documents regarding the Arctic areas and Siberia the Strategy for the development of the Arctic zone of the Russian Federation and ensuring state security for the period up to 2020 February 2013 and the Strategy for socio-economic development of Siberia up to 2020 of 05 June 2010.

${ }^{7}$ Project to increase transport by this route to 80 million tons per year. It is also to include exports of natural gas (as well as its condensate) as well as coal and crude oil from the ports of: Sabetta, Dikson, and Dudinka. It is expected to be finalized by 2024 .
} 
assumptions of the 2015 strategy also took into account the risks associated with the work of US analytical centers on the concept of liquefied gas exports and the shale revolution. The strategy called for reducing the energy intensity of the economy, modernizing and locating the infrastructure of the fuel and energy industry for the purposes of implementing development programs and export concepts of the Russian Federation. The new Strategy assumes that the implementation of its objectives - that is, to obtain the status of a superpower - is associated with the need to correlate sectoral policies. A pro-export approach has been revised so deeply rooted in the content of the strategy of 2003 and 2009 for the rational management of raw materials and the expansion of the public. The strategy provides that the Russian state maintains total control over the transmission and storage system, both by regulating the price of transmission and storage costs, as well as the fact that state monopolies are the recipient of transmission services. The second goal of development of the gas sector was to gain new export capacities by developing the possibility of exporting liquefied gas. Transport policy was also subordinated to these assumptions. The Regulation of the Russian Government of March 18, 2016 indicates projects supporting gas and oil transport in the new directions provided for in the Strategy. These projects envisage the creation of new seaports (e.g. on the Yamal Peninsula), the construction of icebreakers, or the connection of seaports with other transport infrastructure. In addition, Regulation No. 2101 of the Government of the Russian Federation of 30 September 2018 provides for the implementation of activities for the development of transport (pipeline) transportation of crude oil and refined products, as well as gas and gas condensate. In this context, one of the projects was the development (in 2018) of pipelines (as part of the "North" project) to increase the supply (up to 25 million tons per year) of crude oil products to the port of Primorsk. Transport policy also takes into account the Far East expansion direction. This is evidenced by the content of Regulation No. 436 of the Russian Government of March 14, 2019 on the investment project for the construction of a liquefied gas transshipment terminal in Kamchatka Krai (Russian Governement, 2019).

In May 2019, President Vladimir Putin, by decree, approved the new Energy Security Doctrine of the Russian Federation (Ukaz, 2019), which was a development of a classified document adopted on November 29, 2012. The strategic goal indicated in the document is to ensure the country's energy security, and in particular to protect Russian political and economic interests, which fully corresponds to the provisions of the document on a broader scope, which is the Strategy of economic security of the Russian Federation until 2030 (Ukaz, 2017), postulating obtaining a status of a modern state, resistant to fluctuations in the economy, capable of dominating markets and obtaining production capacity in areas affecting Russia's energy security. The doctrine of economic security takes into account the current conditions of Russia, related to the consequences of economic sanctions imposed on Russia after the annexation of Crimea, limiting the inflow of capital and modern technology, so important in the energy sector. The dynamic situation of the world economy and the location of Asian countries as a center of economic development is also an important challenge on the basis of the document in question. The energy policies of developed countries were also directed towards a low-carbon and energy-saving economy. The doctrine, like all previous strategic documents in the field of energy policy, supports the thesis that energy policy and the possibilities of the fuel and energy complex are one of the most important factors of Russian security policy and a tool for shaping international order and determining the political position of the state, as well as is intended to modernize the economy and improve the quality of life of citizens. 


\section{CONCLUSIONS}

Russian energy policy is currently in a period of transformation, the essence of which is to adapt the fuel and energy sector to the anticipated transformations in the global energy market. However, assessments of the reform concept for this sector of the Russian economy cannot be limited to measures aimed at increasing efficiency, as it plays a decisive role in building the state's potential and co-creates the essential instruments of international influence a radical change in Russian strategic goals. Only the formula of conducted activities has been reformatted, which are currently focusing on counteracting American export policy and adapting own exports to the specific needs of the global energy market. These conditions forced a change in the way the Russian fuel and energy sector functions and energy policy in the internal market. The potential decrease in revenues from the export of raw materials and the scale of necessary investments in the fuel and energy industry may threaten the financial stability of the state, and certainly disrupt the implementation of planned modernization and development processes.

What determines the need for modifications to the strategic assumptions of energy policy are undoubtedly the EU sanctions imposed on Russia after the annexation of Crimea. They block access to capital and technology necessary for the modernization of the fuel and energy industry. The time and scope of sanctions significantly affects the achievement of strategic goals. The factor determining the effectiveness of Russia's activities in the energy sector is also the development of energy raw material prices. In this respect, the possibilities of FR influence may be limited. The extent to which energy policy goals are achieved depends on how relations with China are shaped, because cooperation, or lack thereof, will determine the success of expansion in the east.

A positive factor affecting implementation options is the way the strategy is prepared and implemented. They cover long periods and are constantly updated. They indicate long-term goals and operational activities to achieve them. Energy policy is closely related to transport policy, which increases the effectiveness of the stated goals. The implementation of large investment projects is supervised by central authorities. The stability of the Russian political scene is also important, as it implements the assumptions of energy and other sectoral policies influencing its implementation in a very consistent manner, making appropriate adjustments when the need arises.

\section{REFERENCES}

Czachor, R. (2008). Polityczne uwarunkowania budowy Gazociagu Pótnocnego: polityka energetyczna Federacji Rosyjskiej a solidarność europejska (Political circumstances for the construction of the Northern Gas Pipeline: the energy policy of the Russian Federation and European solidarity) [in:] Winnicki, Z.J., Baluk, W., ed., Badania wschodnie. Polityka wewnętrzna i międzynarodowa (Eastern research. Internal and international policy). Wrocław: Oficyna Wydawnicza Arboretum.

Fredholm, M. (2005). The Russian Energy Strategy \& Energy Policy: Pipeline diplomacy or mutual dependence?, Camberley, England: Conflict Studies Research Centre, 2005.

Goldmann, M.I. (2008). Putin, Power, and the New Russia: Petrostate. New York: Oxford University Press.

Gołaś, K. (2011). Region Kaukazu w polityce Federacji Rosyjskiej - wybrane aspekty (Caucasian region in Russian Federation politics - selected aspects). „Przeglad Geopolityczny” ("Geopolitical Review"), t. 3. 
Gryz, J. (2009). Geopolityczne aspekty polityki energetycznej Federacji Rosyjskiej, (Geopolitical aspects of the Russian Federation's energy policy). "Przeglad Geopolityczny" ("Geopolitical Review"), t. 1.

Hill, F. (2004). Energy Empire: oil, Gas and Russia Revival, brookings.edu [Access: 25.10.2019]. Access on the internet: http://www.brookings.edu/research/articles/2004/09/russiahill.

Kardaś, S. (2017). Na rozdrożu, Aktualne problemy rosyjskiego sektora gazowego (At the crossroads, current problems of the Russian gas sector). Warsaw: OSW.

Kozłowski, S.C. (2017). Zwrot Ku Azji - wizja i Strategia polityki Federacji rosyjskiej (Return towards Asia - the vision and strategy of the Russian Federation). "Nowa Polityka Wschodnia" ("New Eastern Policy"), Vol. 1/2017.

Madera, A.J. Polityka energetyczna Rosji (Russian energy policy) [Access: 18.09.2019]. Access on the internet: http://www.wnp.pl/artykuly/polityka-energetyczna-rosji,5610.html.

Mickiewicz, P. (2018). W poszukiwaniu teoretycznych podstaw rosyjskiego myślenia strategicznego ery W. Putina (In search of the theoretical foundations of Russian strategic thinking of the W. Putin era). "Rocznik Bezpieczeństwa Międzynarodowego" ("Yearbook of International Security”), Vol. 12, No. 2.

Musiałek, P. (2013). Geoekonomia czy geopolityka? Strategia Gazpromu na rynku gazu państw Unii Europejskiej (Geoeconomics or geopolitics? Gazprom's strategy in the gas market of European Union countries). „Kultura i Polityka: zeszyty naukowe Wyższej Szkoły Europejskiej im. Ks. J. Tishnera w Krakowie” (,,Culture and Policy: scientific notebooks of the Higher School of Europe im. Fr. J. Tishner in Krakow”), nr 14/2013.

Musiałek, P. Koniec projektu Nabucco West. Spektakularny sukces Rosji i klęska unijnej dyplomacji (End of the Nabucco West project. Russia's spectacular success and the defeat of EU diplomacy) [Access: 18.10.2019]. Access on the internet: http://eksperci.kj.org.pl/wp-content/ uploads/2013/07/Nabucco-komentarz.pdf.

Paszyc, E., Wiśniewska, I. (2005). The Russian Economy Under Putin. Growth factors and impediments to economic development, CES Studies.

Potulski, J. (2011). Rosja Putina - polityczny projekt budowy rosyjskiej państwowości (Putin's Russia - a political project to build Russian statehood). „Nowa Polityka Wschodnia” („New Eastern Policy”), nr 1 (1).

Raś, M. (2015). Polityka Rosji wobec Ukrainy i jej implikacje dla ładu międzynarodowego $w$ Europie (Russia's policy towards Ukraine and its implications for international governance in Europe) [in:] Czornik K., Lakomy, M., Stolarczyk, M. Implikacje konfliktu ukraińskiego dla polityki zagranicznej i bezpieczeństwa Polski. Aspekty polityczne, wojskowe, gospodarcze oraz spoteczne (Implications of the Ukrainian conflict for Poland's foreign and security policy. Political, military, economic and social aspects). Katowice: Wydawnictwo Regionalnego Ośrodka Debaty Międzynarodowej przy Fundacji na rzecz Wspierania Edukacji i Rozwoju Samorządności wśród młodzieży Viribus Unitis.

Ruszel, M. (2011). Geopolityczne uwarunkowania bezpieczeństwa energetycznego Polski. „Spoteczeństwo i Polityka” nr 2 (27).

Rzeszutko-Piotrowska, M. (2014). Aktywność Federacji Rosyjskiej w regionie Arktyki wybrane problemy rywalizacji mocarstw. „Rocznik Bezpieczeństwa Międzynarodowego”, Vol. 8, No. 1.

Sergunin, A., Konyshev, V. (2018). Russia's Arctic Strategy [in:] Studin, I., ed., Russia, strategy, policy and administration. London: Palgrave Macmillan. 
Szoszyn, R. Arktyczne tajemnice Moskwy [Access: 25.08.2019 r.]. Access on the internet: https://www.rp.pl/Rosja/190739800-Arktyczne-tajemnice-Moskwy.html.

Włodkowska-Bagan, A. (2017). Polityka Rosji na obszarze poradzieckim (Russia's policy in the post-Soviet area). „Wschodni Rocznik Humanistyczny” (,Eastern Humanities Yearbook”), Vol. XIV, No. 3.

Wyganowski, J. (2014). Dlaczego Rosja bierze Krym? (Why does Russia take Crimea?), „Energia Gigawat”, $\mathrm{nr} 3 / 2014$ [Access: 22.11.2019]. Access on the internet: https://www.cire.pl/pliki/2/dlaczegorosjabierzekrym.pdf.

Zolotova, M. (2014). Arktike net alternativi Odnako [Access: 20.11.2019]. Access on the internet: http://www.odnako.org/almanac/material/arktike-net-alternativi/.

DOI: $10.7862 /$ rz.2020.hss.37

The text was submitted to the editorial office: May 2020.

The text was accepted for publication: September 2020. 
